Dikirim: 14 September 2015 Diterbitkan: 1 Mei 2016

\section{Kepatuhan bidan Puskesmas dalam penerapan antenatal care terpadu berkualitas, deteksi penyakit dan komplikasi pada ibu hamil}

Compliance of midwife primary health center in implementation of the antenatal care integrated quality, disease detection and complications in pregnant women

Siti Sholikhah ${ }^{1}$, Heru Pradjatmo ${ }^{2}$, Mohammad Hakimi $^{3}$

\section{Abstract}

Purpose: This research aimed to determine the relationship of midwife's compliance in the implementation of the antenatal care (ANC) integrated quality with disease detection and complications in pregnant women. Methods: This research was an observational study with a retrospective cohort design. The sample was midwives who serve pregnant women in a primary health center, involving 125 midwives. The place of research was in 21 health centers throughout Kulon Progo. Research instruments used a questionnaire, with total sampling. Data analysis used: univariable analysis to determine the distribution of the data, bivariable with chi-square tests, multivariable with linear regression tests with $95 \% \mathrm{Cl}$ and significance of $p=0.05$, and a qualitative analysis. Results: Midwives' compliance to the standard operating procedure has a $35 \%$ greater chance of detecting complications and illness in pregnant women than the midwife who did not follow standard operating procedure. Not all midwives in primary health care comply with ANC integrated quality. Conclusion: This study contributes to an understanding that compliance of midwives to ANC integrated quality is important as an effort to detect complications in pregnant women. The health office should establish a team for socialization, supervision, and assistance in the implementation of ANC integrated quality.

Keywords: compliance; midwives; integrated ANC; detection of complication; pregnant woman

\footnotetext{
${ }^{1}$ Dinas Kesehatan Kabupaten Kulon Progo, D.I. Yogyakarta

${ }^{2}$ Departemen Obstetri dan Ginekologi, Fakultas Kedokteran, Universitas Gadjah Mada

${ }^{3}$ Departemen Biostatistik, Epidemiologi, dan Kesehatan Populasi, Fakultas Kedokteran, Universitas Gadjah Mada
} 


\section{PENDAHULUAN}

Kematian ibu telah lama menjadi prioritas kesehatan global dan merupakan target dalam tujuan pembangunan milenium PBB (MDG) (1). Angka kematian ibu di Indonesia mencapai 359 per 100.000 $\mathrm{KH}$ (2). Akselerasi penurunan kematian ibu merupakan fokus dari strategi global untuk kesehatan perempuan dan anak yang telah diluncurkan oleh Sekretaris Jenderal Perserikatan Bangsa Bangsa (3). Di Daerah Istimewa Yogyakarta tahun 2012 jumlah kematian ibu 46 kasus (4).

WHO menyatakan penyebab kematian ibu di berbagai negara adalah perdarahan 27,1\%, gangguan tekanan darah $14,0 \%$, sepsis $10 \%$, abortus tidak aman $7,9 \%$, emboli air ketuban 3,2\%, dan infeksi lain 9,6\%. Sebagian besar komplikasi ini bisa dicegah dengan memberikan ANC yang berkualitas (5). Terdapat 287.000 kematian ibu di dunia pada tahun 2010, lebih dari setengahnya berada pada kondisi risiko seumur hidup. Di Sub Sahara, kematian ibu karena komplikasi kehamilan lebih tinggi (1). Penyebab kematian ibu tertinggi di Indonesia tercatat karena perdarahan (2).

Di Kabupaten Kulon Progo, kematian ibu terbanyak disebabkan komplikasi atau penyakit yang menyertai ibu hamil. Penyebab kematian ibu dalam 5 tahun terakhir dari tahun 2009-2013 adalah eklampsia 9 kasus, penyakit jantung 7 kasus, ashma dan broncho pneumonia 5 kasus, gagal ginjal 2 kasus, perdarahan 2 kasus, emboli air ketuban 2 kasus, hepatitis, kanker payudara dan HIV/AIDS masing-masing 1 kasus (6).

Pelayanan ANC merupakan ukuran yang diakui untuk mengurangi kematian ibu dan bayi (7). Setiap ibu hamil diharapkan dapat menjalankan kehamilan sehat, bersalin dengan selamat, serta melahirkan bayi yang sehat, oleh karena itu setiap ibu hamil harus dengan mudah dapat mengakses fasilitas kesehatan untuk mendapatkan pelayanan sesuai standar (8).

Kementerian Kesehatan Republik Indonesia telah menyusun pedoman pelayanan antenatal terpadu, komprehensif dan berkualitas tahun 2009. Kebijakan pelayanan tersebut tidak hanya fokus pada standar layanan, namun memperhatikan keterpaduan layanan program lain, termasuk pemeriksaan oleh dokter umum minimal satu kali selama periode kehamilan. Penelitian ini bertujuan mengetahui hubungan kepatuhan bidan melaksanakan prosedur tetap layanan ANC terpadu berkualitas dengan deteksi komplikasi dan penyakit pada ibu hamil.

\section{METODE}

Penelitian observasional ini menggunakan rancangan penelitian studi cohort retrospektif (9). Sampel adalah bidan yang melayani pemeriksaan ibu hamil di Puskesmas sebanyak 125 bidan. Lokasi penelitian di 21 Puskesmas se-Kabupaten Kulon Progo. Cara pengambilan sampel dilakukan dengan dua tahap. Pertama, bidan diberikan kuesioner mengenai karakteristik bidan, pengenalan seputar ANC terpadu di puskesmas dan pengetahuan bidan tentang ANC terpadu berkualitas. Kedua, peneliti menelusuri catatan hasil layanan ANC terpadu pada status ibu hamil sesuai dengan nama bidan yang paling akhir memeriksa ibu.

Kriteria inklusi penelitian ini adalah bidan yang mempunyai tugas memberikan layanan ANC terpadu berkualitas pada ibu hamil di Puskesmas. Variabel independen adalah kepatuhan bidan dalam penerapan ANC terpadu berkualitas, sedangkan variabel dependen adalah deteksi komplikasi/penyakit pada ibu hamil. Variabel luar adalah pendidikan, pengetahuan, masa kerja dan beban kerja program.

Instrumen yang digunakan meliputi kuesioner tentang identitas bidan, informasi tentang ANC terpadu yang diperoleh bidan, pengetahuan bidan dan lembar wawancara. Analisis data kuantitatif dengan tahapan berikut; a) analisis deskriptif; b) analisis inferensial, dengan menggunakan uji Chi-square pada tingkat kemaknaan $\mathrm{p}<0.05$ dan CI 95\%. Nilai RR digunakan untuk melihat seberapa kuat hubungan tersebut; dan c) analisis multivariat dengan uji regresi logistik dengan tingkat kemaknaan $\mathrm{p}<0.05$, CI $95 \%$, nilai $\mathrm{R}^{2}$, dan nilai deviance. Data kualitatif dilakukan untuk memperkuat data kuantitatif dengan menganalisis hasil dari wawancara mendalam.

\section{HASIL}

Tabel 1 menunjukkan gambaran karakteristik responden penelitian. Proporsi kepatuhan bidan dalam pelayanan ANC hampir sama besar. Semua bidan yang terlibat dalam penelitian ini memiliki pengetahuan yang baik, dan hampir 90\% berpendidikan diploma 3 Kebidanan. Lima puluh dua persen bidan bekerja lebih dari 20 tahun. Sementara, masyoritas bidan memiliki beban kerja memegang 1 program di luar kesehatan ibu dan anak (KIA) dan layanan KIA. 
Tabel 1. Distribusi frekuensi karakteristik responden

\begin{tabular}{|c|c|}
\hline Karakteristik & $\begin{array}{c}\text { Persentase } \\
\%(n=125)\end{array}$ \\
\hline \multicolumn{2}{|l|}{ Kepatuhan ANC } \\
\hline Patuh & 50,4 \\
\hline Tidak Patuh & 49,6 \\
\hline \multicolumn{2}{|l|}{ Deteksi penyakit } \\
\hline Terdeteksi & 66,4 \\
\hline Tidak terdeteksi & 33,6 \\
\hline \multicolumn{2}{|l|}{ Pendidikan ibu } \\
\hline D 1 Kebidanan & 12,0 \\
\hline D 3 Kebidanan & 88,0 \\
\hline \multicolumn{2}{|l|}{ Pengetahuan } \\
\hline Baik & 100 \\
\hline Kurang & - \\
\hline \multicolumn{2}{|l|}{ Masa kerja } \\
\hline$<20$ th & 48,0 \\
\hline$\geq 20$ th & 52,0 \\
\hline \multicolumn{2}{|l|}{ Beban kerja } \\
\hline 2 Prog + KIA & 26,4 \\
\hline 1 Prog + KIA & 46,4 \\
\hline KIA & 27,2 \\
\hline
\end{tabular}

Tabel 2 menunjukkan bidan yang patuh terhadap protap ANC terpadu berkualitas akan mendeteksi komplikasi dan penyakit pada ibu hamil lebih banyak, jika dibandingkan dengan bidan yang tidak patuh. Bidan yang patuh mempunyai peluang $35 \%$ lebih besar melakukan deteksi komplikasi bila dibandingkan dengan bidan yang tidak patuh.

Tabel 2. Relative risk deteksi penyakit berdasarkan kepatuhan bidan

\begin{tabular}{|c|c|c|c|c|c|c|c|c|}
\hline \multirow[t]{3}{*}{ Variabel } & \multicolumn{4}{|c|}{ Deteksi penyakit } & \multirow{3}{*}{$\mathrm{X}^{2}$} & \multirow{3}{*}{$p$} & \multirow{3}{*}{ RR } & \multirow{3}{*}{ CI 95\% } \\
\hline & \multicolumn{2}{|c|}{ Terdeteksi } & \multicolumn{2}{|c|}{ Tidak } & & & & \\
\hline & $\mathrm{n}$ & $\%$ & $\mathbf{n}$ & $\%$ & & & & \\
\hline \multicolumn{9}{|l|}{ Kepatuhan } \\
\hline Patuh & 48 & 76,2 & 15 & 23,8 & 5,45 & $0,02^{*}$ & 1,35 & $1,04-1,74$ \\
\hline Tidak & 35 & 56,4 & 27 & 43,6 & & & 1 & \\
\hline Patuh (R) & & & & & & & & \\
\hline
\end{tabular}

Tabel 3 menunjukkan bidan dengan pendidikan D3-D4 akan mendeteksi komplikasi lebih besar, bila dibandingkan dengan bidan pendidikan D1 saja. Bidan yang mempunyai pendidikan D3-D4 mempunyai peluang sebesar $75 \%$ lebih besar dalam melakukan deteksi komplikasi bila dibandingkan dengan bidan yang berpendidikan D1.

Masa kerja bidan yang sudah 20 tahun atau lebih akan mendeteksi komplikasi/penyakit lebih besar, bila dibandingkan dengan bidan yang mempunyai masa kerja di bawah 20 tahun. Bidan yang mempunyai masa kerja 20 tahun atau lebih mempunyai peluang $41 \%$ lebih besar dalam mendeteksi komplikasi bila dibandingkan dengan bidan yang mempunyai masa kerja di bawah 20 tahun. Sementara, beban kerja bidan tidak berpengaruh terhadap deteksi komplikasi dan penyakit ibu hamil (Tabel 3).

Tabel 3. Relative risk deteksi penyakit berdasarkan variabel luar

\begin{tabular}{|c|c|c|c|c|c|c|c|c|}
\hline \multirow{3}{*}{ Variabel } & \multicolumn{4}{|c|}{ Deteksi penyakit } & \multirow{3}{*}{$x^{2}$} & \multirow{3}{*}{$\mathbf{p}$} & \multirow{3}{*}{$\mathbf{R R}$} & \multirow{3}{*}{ CI 95\% } \\
\hline & \multicolumn{2}{|c|}{ Terdeteksi } & \multicolumn{2}{|c|}{ Tidak } & & & & \\
\hline & $\mathbf{n}$ & $\%$ & $\mathbf{n}$ & $\%$ & & & & \\
\hline \multicolumn{9}{|l|}{ Pendidikan } \\
\hline D3-D4 & 77 & 70,0 & 33 & 30,0 & \multirow{2}{*}{\multicolumn{2}{|c|}{$5,320,02^{*}$}} & 1,75 & $1,08-2,82^{*}$ \\
\hline $\mathrm{D} 1(\mathrm{R})$ & 6 & 40,0 & 9 & 60,0 & & & 1 & \\
\hline \multicolumn{9}{|c|}{ Pengetahuan } \\
\hline Baik & \multirow[t]{2}{*}{83} & 66,4 & 42 & 33,6 & \multirow[t]{2}{*}{-} & \multirow[t]{2}{*}{-} & - & \\
\hline Tidak(R) & & & & & & & 1 & \\
\hline \multicolumn{9}{|l|}{ Masa kerja } \\
\hline$>=20$ & 47 & 78,3 & 13 & 21,7 & \multirow[t]{2}{*}{7,36} & \multirow[t]{2}{*}{0,01} & 1,41 & \multirow[t]{2}{*}{$1,09-1,82$} \\
\hline$<20$ (R) & 36 & 55,4 & 29 & 44,6 & & & 1 & \\
\hline \multicolumn{9}{|c|}{ Beban kerja } \\
\hline KIA & 19 & 70,6 & 14 & 29,4 & \multirow[t]{2}{*}{1,59} & 0,26 & 0,82 & $0,56-1,17$ \\
\hline $\begin{array}{l}1 \text { program } \\
+ \text { kia }\end{array}$ & 40 & 69,0 & 18 & 31,0 & & 0,87 & 0,98 & $0,74-1,28$ \\
\hline $\begin{array}{l}2 \text { program } \\
+ \text { kia }(\mathrm{R})\end{array}$ & 24 & 57,6 & 10 & 42,4 & & & 1 & \\
\hline
\end{tabular}

Tabel 4 menunjukkan tidak ada hubungan bermakna antara variabel luar dengan variabel bebas. Secara statistik tidak ada hubungan yang bermakna antara pendidikan bidan dengan kepatuhan bidan. Masa kerja secara statistik tidak berpengaruh terhadap kepatuhan bidan terhadap protap (prosedur tetap). Penelitian ini tidak menemukan hubungan beban kerja dengan kepatuhan bidan terhadap protap. Ketentuan tersebut berlaku untuk semua bidan, baik bidan yang mempunyai beban kerja di KIA saja, maupun bidan yang mempunyai beban kerja tambahan di luar KIA.

Tabel 4. Relative risk kepatuhan bidan berdasarkan variabel luar

\begin{tabular}{|c|c|c|c|c|c|c|c|c|}
\hline \multirow{3}{*}{ Variabel } & \multicolumn{4}{|c|}{ Kepatuhan } & \multirow{3}{*}{$\mathbf{x}^{2}$} & \multirow{3}{*}{$\mathbf{p}$} & \multirow{3}{*}{$\mathbf{R R}$} & \multirow{3}{*}{ CI 95\% } \\
\hline & \multicolumn{2}{|c|}{ Patuhi } & \multicolumn{2}{|c|}{ Tidak } & & & & \\
\hline & $\mathbf{n}$ & $\%$ & $\mathbf{n}$ & $\%$ & & & & \\
\hline \multicolumn{9}{|c|}{ Pendidikan } \\
\hline D3-D4 & 57 & 51,8 & 53 & 48,2 & 0,73 & 0,39 & 1,29 & $0,67-2,47$ \\
\hline D1 (R) & 6 & 40,0 & 9 & 60,0 & & & 1 & \\
\hline \multicolumn{9}{|c|}{ Pengetahuan } \\
\hline Baik & 63 & 49,6 & 64 & 50,4 & - & - & - & - \\
\hline Tidak(R) & & & & & & & 1 & \\
\hline \multicolumn{9}{|l|}{ Masa kerja } \\
\hline$>=20$ & 33 & 55,0 & 27 & 45,0 & 0,97 & 0,01 & 1,19 & $0,84-1,68$ \\
\hline$<20(\mathrm{R})$ & 30 & 46,2 & 35 & 53,8 & & & 1 & \\
\hline \multicolumn{9}{|c|}{ Beban kerja } \\
\hline KIA & 18 & 54,5 & 15 & 45,5 & 1,59 & 0,27 & 1,32 & $0,79-2,20$ \\
\hline $\begin{array}{l}1 \text { program } \\
+ \text { kia }\end{array}$ & 31 & 53,5 & 27 & 46,5 & & 0,19 & 1,29 & $0,81-2,07$ \\
\hline $\begin{array}{l}2 \text { program } \\
+ \text { kia (R) }\end{array}$ & 14 & 41,2 & 20 & 58,8 & & & 1 & \\
\hline
\end{tabular}

Tabel 5 menunjukkan perbandingan model regresi logistik. Model terbaik adalah model 2. Kepatuhan bidan terhadap deteksi komplikasi dan penyakit ibu hamil, setelah mengontrol tingkat pendidikan tetap signifikan, dan dalam melakukan deteksi akan 
meningkatkan 3,33 kali lebih besar bila dibandingkan dengan bidan yang tidak patuh.

Tabel 5. Perbandingan model analisis regresi logistik

\begin{tabular}{|c|c|c|c|c|}
\hline & Model1 & Model2 & Model3 & Model4 \\
\hline & $\mathbf{P}$ & $\mathbf{P}$ & $\overline{\mathbf{P}}$ & $\overline{\mathbf{P}}$ \\
\hline & OR & OR & OR & OR \\
\hline & CI 95\% & CI 95\% & CI 95\% & CI 95\% \\
\hline \multicolumn{5}{|l|}{ Kepatuhan } \\
\hline \multirow[t]{3}{*}{ Patuh } & 0,02 & 0,02 & 0,03 & 0,04 \\
\hline & 2,46 & 2,39 & 2,36 & 2,25 \\
\hline & $(1,14-5,31)$ & $(1,09-5,22)$ & $(1,07-5,20)$ & $(1,01-5,04)$ \\
\hline Tidak & 1 & 1 & 1 & 1 \\
\hline \multicolumn{5}{|l|}{ Patuh(R) } \\
\hline \multicolumn{5}{|l|}{ Pendidikan } \\
\hline \multirow[t]{3}{*}{ Tinggi } & & $0,03^{*}$ & & 0,02 \\
\hline & & 3,33 & & 4,49 \\
\hline & & $(1,07-10,37)$ & & $(1,31-15,35)$ \\
\hline Rendah(R) & & 1 & & \\
\hline $\begin{array}{c}\text { Masa kerja } \\
\text { (tahun) }\end{array}$ & & & 0,01 & 0,01 \\
\hline$>=20$ & & & 2,81 & 3,32 \\
\hline$<20$ (R) & & & $(1,26-6,25)$ & $(1,42-7,76)$ \\
\hline$\overline{\mathbf{R}^{2}}$ & 0,03 & 0,06 & 0,08 & 0,11 \\
\hline Deviance & 154,07 & 149,65 & 147,34 & 141,32 \\
\hline $\mathbf{N}$ & 125 & 125 & 125 & 125 \\
\hline
\end{tabular}

Berdasarkan hasil analisis kualitatif, semua bidan sudah pernah mendengar dan terpapar tentang ANC terpadu berkualitas. Sumber informasi tentang ANC terpadu berkualitas $40 \%$ berasal dari Dinas Kesehatan, $35 \%$ dari bidan koordinator KIA dan 24\% dari teman sesama bidan. Protap ANC sudah ada di 21 puskesmas, namun tidak semua puskesmas memasang protap tersebut di ruang periksa KIA. Sebanyak 14,3\% puskesmas tidak memasang protap, 23,8\% puskesmas memasang di luar ruang KIA dan 61,9\% puskesmas memasang protap di ruang KIA. Dari hasil wawancara mendalam juga didapatkan data bahwa angka kepatuhan bidan 50,60\% bukan berarti bidan tidak patuh terhadap protap. Bidan dikatakan patuh bila selama periode kehamilan ibu mendapatkan 19 jenis pelayanan yang harus didapatkan. Faktanya, dari 19 jenis pelayanan, beberapa bukan merupakan kewenangan bidan untuk memberikan, seperti dokter umum, dokter gigi, ahli gizi, P2M dan laboratorium.

Faktor-faktor yang berpengaruh terhadap penerapan ANC terpadu berkualitas meliputi 1) ketersediaan SDM, 2) waktu kunjungan ibu hamil, 3) peran BPS dalam merujuk ibu hamil ke puskesmas, 4) penggunaan format ANC terpadu, 5) kebijakan pembiayaan dan 6) kelengkapan sarana prasarana puskesmas.

\section{BAHASAN}

Secara umum hasil penelitian ini sudah bisa memberikan gambaran kepada kita tentang bagaimana penerapan protap ANC terpadu berkualitas di semua puskesmas di Kulon Progo. Dua puluh satu puskesmas sudah menerima Surat Keputusan Kepala Dinas Kesehatan tentang protap ANC terpadu berkualitas. Faktanya, belum semua puskesmas memasang protap ANC terpadu di ruang periksa KIA. Semua bidan sudah terpapar dan mengetahui tentang ANC terpadu berkualitas, namun persepsi mereka tentang ANC terpadu belum sama. Angka kepatuhan bidan terhadap protap 50,40\% menggambarkan bahwa pelayanan ANC terpadu berkualitas belum dilaksanakan sesuai standar yang ada. Ini adalah masalah dalam pelayanan ANC di Kabupaten Kulon Progo.

Penelitian yang dilakukan Oster et.al. mengatakan bahwa informasi pelayanan kesehatan khususnya informasi tentang komplikasi kehamilan dan persalinan hanya didapat oleh kurang dari 50\%. Kondisi ini menunjukkan masalah dalam pelayanan ANC. Masalah dalam mendapatkan pelayanan kesehatan selama hamil merupakan salah satu determinan kejadian komplikasi persalinan. Masih dalam jurnal yang sama dikatakan bahwa ibu yang menghadapi masalah dalam mendapatkan pelayanan kesehatan lebih berisiko 1,15 kali mengalami komplikasi persalinan dibandingkan ibu yang tidak memiliki masalah dalam mendapatkan pelayanan kesehatan. Masih banyak ibu yang menghadapi masalah dalam mendapatkan pelayanan kesehatan, terutama mendapatkan determinan kejadian komplikasi persalinan (10).

Pernyataan tersebut sejalan dengan penelitian yang dilakukan oleh Colti Sistriarani dalam faktor-faktor maternal dan kualitas pelayanan ANC yang berisiko terhadap kejadian BBLR di RSUD Banyumas Jawa Tengah. Ibu yang mempunyai masalah atau penyakit selama kehamilannya seperti, hipertensi, pre-eklamsia, eklamsia, kekurangan energi kronik (KEP), jantung, TBC dan Anemia, mempunyai risiko 2,91\% melahirkan bayi BBLR dibandingkan ibu yang tidak mempunyai penyakit tersebut dalam kehamilannya. Ibu yang mendapatkan kualitas pelayanan ANC kurang baik, berpeluang 5,85 kali untuk melahirkan bayi BBLR dibandingkan dengan ibu yang mendapatkan kualitas pelayanan ANC yang baik (11). 
Angka kepatuhan pada hasil penelitian ini adalah 50,4\%. Hal ini berdampak pada hasil deteksi komplikasi dan penyakit pada ibu hamil yang baru mencapai 66,40\%. Kementerian kesehatan Republik Indonesia menargetkan deteksi komplikasi dan penyakit pada ibu hamil oleh petugas sebesar $100 \%$. Bila angka ini benar, maka tidak mengherankan jika kematian ibu dan bayi sulit diturunkan terutama yang disebabkan karena komplikasi atau penyakit yang menyertai kehamilan.

Hasil penelitian ini menunjukkan bahwa ada hubungan yang signifikan antara pendidikan dan masa kerja dengan deteksi komplikasi penyakit pada ibu hamil. Myers et al. Singer and Bruhns dan Strober menyatakan bahwa pendidikan dan pengalaman kerja adalah dua bentuk modal individu manusia yang paling mungkin untuk memperoleh selama karier mereka. Sebagian besar organisasi menggunakan pendidikan sebagai indikator untuk seseorang mempunyai tingkat keterampilan dan produktivitas kerja yang berbeda (12).

Individu dengan tingkat pendidikan yang lebih tinggi memiliki kecerdasan cairan dan kecerdasan mengkristal yang lebih besar. Kecerdasan cairan mengacu pada kapasitas memori kerja, penalaran abstrak, perhatian, dan kompleks pengolahan informasi, sedangkan kecerdasan mengkristal mengacu pengetahuan umum, luasnya kosakata, dan pemahaman verbal berhubungan dengan Sekolah Menengah Kejuruan. Penelitian tersebut mengatakan bahwa pendidikan berpengaruh positif terhadap tugas inti atau kinerja, perilaku dan produktivitas seseorang (13). Peningkatan pengalaman kerja para pekerja cenderung menunjukkan kinerja yang relatif lebih baik (14).

Senada dengan hasil penelitian ini, masa kerja berhubungan dengan deteksi komplikasi dan penyakit yang menyertai kehamilan. Semakin lama masa kerja, seseorang semakin mampu melakukan deteksi adanya komplikasi atau penyakit pada ibu hamil. Berbeda dengan penelitian lain yang menemukan tidak ada hubungan bermakna antara masa kerja dengan kinerja bidan di puskesmas wilayah Kecamatan Pulau Dullah Selatan Kabupaten Maluku Tenggara (15).

Penelitian ini tidak menemukan hubungan signifikan antara beban kerja dengan deteksi. Hasil ini serupa dengan penelitian sebelumnya yang menemukan tidak ada hubungan beban kerja dengan kinerja karyawan. Beban kerja tidak berpengaruh secara langsung terhadap kinerja karyawan. Akan tetapi, beban kerja berpengaruh terhadap stres yang dapat memengaruhi kinerja para karyawan. Bisa dikatakan bahwa ukuran beban kerja tidak akan memengaruhi kinerja karyawan selama mereka tidak mengalami stres. Secara umum beban kerja tidak berhubungan dengan kinerja karyawan(16).

Berbeda dengan hasil penelitian lain yang membuktikan bahwa variabel beban kerja (X3) berpengaruh positif dan signifikan terhadap Kinerja Bidan. Semakin meningkat beban kerja yang dimiliki bidan, maka semakin meningkat kinerja bidan di Instalasi Rawat Inap Ruang Obstetri RSUP Dr. Kariadi Semarang (17).

Penelitian ini menemukan tidak ada hubungan yang bermakna antara pendidikan bidan, masa kerja bidan dan beban kerja bidan dengan kepatuhan bidan. Hasil serupa ditemukan pada penelitian lain yang menemukan tidak ada hubungan yang signifikan antara tingkat pendidikan ibu hamil dengan kepatuhan ibu hamil dalam ANC (18).

Penelitian sebelumnya menemukan tidak ada hubungan antara variabel lama kerja dengan tingkat kepatuhan tenaga kesehatan dalam menjalankan SOP pertolongan persalinan (19). Pada umumnya seseorang yang sudah lama bekerja pada bidang tugasnya, makin mudah untuk memahami tugasnya tersebut, sehingga memberi peluang untuk meningkatkan prestasi serta beradaptasi dengan lingkungan tempat ia berada.

Hasil penelitian ini menunjukkan ada hubungan bermakna antara kepatuhan dengan deteksi komplikasi dan penyakit ibu hamil setelah dikontrol dengan variabel pendidikan dan masa kerja. Hasil penelitian ini berbeda dengan penelitian sebelumnya. Penelitian tentang pengaruh pendidikan dan pengalaman kerja terhadap kinerja pekerja di pabrik chitoo gula di kota Cittoor di India Selatan menemukan kinerja yang ditunjukkan oleh karyawan bervariasi karena kualifikasi pendidikan mereka. Kecenderungan umumnya adalah dengan peningkatan kualifikasi pendidikan, kinerja karyawan akan menurun. Namun, orang-orang yang hanya memiliki pendidikan menengah tinggi melakukan pekerjaan lebih baik daripada mereka yang telah menyelesaikan hanya pendidikan menengah dan ini adalah pengecualian untuk aturan umum di atas. Kinerja karyawan secara bertahap meningkat dengan pengalaman mereka dan setelah pengalaman 20 tahun kinerja hasilnya semakin rendah. Hal ini mungkin disebabkan oleh kenyataan bahwa karyawan kehilangan minat dalam pekerjaan mereka karena telah melakukan pekerjaan mereka untuk waktu yang lama dan mereka merasa bosan dalam bekerja sehingga hasil pekerjaan lebih rendah. Perlu dicatat bahwa hasil ini berasal dari studi pada 
buruh dan bukan pada profesional warna kulit putih (20).

\section{SIMPULAN}

Semakin patuh bidan terhadap prosedur tetap, maka semakin terdeteksi komplikasi atau penyakit penyerta kehamilan, namun belum semua bidan patuh. Sebaiknya bidan puskesmas menggunakan format baku dalam menerapkan ANC berkualitas. Kepala puskesmas perlu menjadwalkan dokter umum, dokter gigi dan petugas gizi untuk mendukung penerapan ANC terpadu berkualitas di puskesmas. Dinas Kesehatan Kabupaten perlu melakukan sosialisasi bertahap dan komprehensif, supervisi dan pendam- pingan penerapan ANC terpadu di semua puskesmas.

\footnotetext{
Abstrak

Tujuan: Penelitian ini bertujuan untuk mengetahui hubungan kepatuhan bidan dalam pelaksanaan pelayanan terpadu antenatal care (ANC) dengan deteksi penyakit dan komplikasi pada ibu hamil. Metode: Penelitian ini bersifat observasional dengan rancangan studi kohort retrospektif. Sampel adalah bidan yang melayani ibu hamil di Puskesmas, dan melibatkan 125 bidan. Tempat penelitian: 21 puskesmas di Kulon Progo. Instrumen penelitian menggunakan kuesioner, dan teknik sampling adalah total sampel. Analisis data adalah univariabel untuk menentukan distribusinya data, bivariabel dengan chi-square, multivariabel dengan regresi linier dengan CI 95\% dan signifikansi $\mathrm{p}=0,05$, dan analisis kualitatif. Hasil: Kepatuhan bidan terhadap prosedur operasi standar memiliki kesempatan 35\% lebih besar untuk mendeteksi komplikasi dan penyakit pada ibu hamil daripada bidan yang tidak mengikuti standar prosedur. Tidak semua bidan Puskesmas sesuai dengan kualitas ANC terpadu. Simpulan: Penelitian ini memberikan kontribusi pemahaman bahwa kepatuhan bidan terhadap kualitas ANC terpadu sangat penting sebagai upaya untuk mendeteksi komplikasi pada wanita hamil. Dinas Kesehatan harus membentuk tim sosialisasi, supervisi, dan bantuan dalam pelaksanaan ANC kualitas terpadu.
}

Kata kunci: kepatuhan; bidan; ANC terintegrasi; deteksi komplikasi; ibu hamil

\section{PUSTAKA}

1. Say L, Chou D, Gemmill A, Tunçalp Ö, Moller A-B, Daniels J, et al. Global causes of maternal death: a WHO systematic analysis. Lancet Glob Heal. 2014 Jun;2(6).

2. BPS, BKKBN. Indonesia Demographic and Health Survey 2012 Statistics Indonesia National Population and Family Planning Board Ministry of Health MEASURE DHS ICF International. Jakarta; 2013.

3. Hogan MC, Foreman KJ, Naghavi M, Ahn SY, Wang M, Makela SM, et al. Maternal mortality for 181 countries, 1980-2008: a systematic analysis of progress towards Millennium Development Goal 5. Lancet. World Health Organization, Geneva; 2010 May 8;375(9726):1609-23.

4. Dinkes Prov. DIY. Profil Kesehatan Provinsi Daerah Istimewa Yogyakarta Tahun 2012. Yogyakarta; 2013.

5. WHO, UNICEF. Revised 1990 Estimated of Maternal Mortality: New Approach. Geneva; 1996.

6. Progo/ DKKK. Profil Kesehatan Kabupaten Kulon Progo Tahun 2014 (Data 2013). 2014.

7. Moller B, Lushino O, Meirik O, Gebre-Medhin M, Lindmark G. A study of antenatal care at village level in rural Tanzania. Int J Gynecol Obstet. 1989 Oct;30(2):123-31.

8. Kementerian Kesehatan. Pedoman Pelayanan Antenatal Terpadu. Jakarta; 2012.

9. Sastroasmoro S, Ismael S. Dasar-dasar Metodologi Penelitian Klinis. Edisi ke-4. Jakarta: Sagung seto; 2011.

10. Simarmata OS, Armagustini Y, Bisara D. Determinan Kejadian Komplikasi Persalinan di Indonesia (Analisis Data Sekunder Survei Demografi dan Kesehatan Indonesia Tahun 2007). J Ekol Kesehat. 2012;11(1).

11. Sistiarani C. aktor Maternal dan Kualitas Pelayanan Antenatal yang Berisiko terhadap Kejadian Berat Badan Lahir Rendah (BBLR) Studi Pada Ibu Yang Periksa Hamil Ke Tenaga Kesehatan dan Melahirkan di RSUD Banyumas Tahun 2008. Unversitas Diponegoro; 2008.

12. Frost JJ, Benson Gold R, Frohwirth L, Blades N. Variation in Service Delivery Practices Among Clinics Providing Publicly Funded Family Planning Services in 2010. New York; 2012.

13. Ng TWH, Feldman DC. How Broadly Does Education Contribute to Job Performance? Pers Psychol. 2009;62:89-134.

14. Kuncel NR, Hezlett SA, Ones DS. Academic Performance, Career Potential, Creativity, and Job Performance: Can One Construct Predict Them All? J Pers Soc Psychol. 2004 Jan;86(1):148-61.

15. Palutturi S. Determinan Kinerja Bidan di Puskesmas Tahun 2006. J Manaj Pelayanan Kesehat. 2007;10(4).

16. Mudayana AA. Hubungan Beban Kerja dengan Kinerja Karyawan di Rumah Sakit Nur Hidayah Bantul. J Kesehat Masy (Journal Public Heal. 2013 Apr 13;6(1).

17. Trisianawati D. Pengaruh Motivasi Kerja, Disiplin Kerja Dan Beban Kerja Terhadap Kinerja Bidan Di Instalasi Rawat Inap Ruang Obstetri Rsup Dr. Kariadi Semarang. Fakultas Ekonomika dan Bisnis; 2014.

18. Zahroh L, Wulandari A. Faktor-faktor yang mempengaruhi kepatuhan antenatal care (ANC) 
Pada ibu hamil trimester iii di wilayah kerja UPTD Puskesmas Tunggangri Kecamatan Kalidawir

19. Retnaningsih E. Determinan motivasi bidan dalam mematuhi sop pertolongan persalinan Di Kabupaten Banyuasin dan Kota Palembang
Kabupaten Tulungagung. J Str [Internet]. 2014;3(1). Available from:

Lpublikasi.stikesstrada.ac.id

Provinsi Sumatera Selatan tahun 2010. J Pembang Mns. 2012;6(1).

20. Kotur BR, Anbazhagan S. Education and Work-Experience-Influence on the Performance. IOSR J Bus Manag Ver III. 2014;16(5):104-10 
Berita Kedokteran Masyarakat, Volume 32 No. 5 Tahun 2016 